で行なわれている成人鈵検彰は，数種に限られており， 個々の疾病は判明しても総合診断は明らかにならないの が現状のようです。双閻ドックは，数十項目或は，数 百項目の検查をするので非常に信頼の高い謗断が得られ ます. 然し, 人員, 費用の点で必ずしも万人向とはいえ ないでしょう．特に困るのは，入院を要するととです。 現代社会で多忙な每日を送る人々にとって，2日，3日 と入院するととが，自分自身の健康のためとはいいなが ら，できにくい場合が多いのではないでしょうか。

この度，東芝中央病院では，䍏者の久点を補い，多種 目の検查を短時間に，多人数，外来で，しかも僅かな費 用で笑施することのできる，医用機器とComputerを淔 結した system による，わが国初めての，総合的，多角 的, 健康誩断施設が東芝総合健診センターとして, 発足 しましたので報台致します。.

\section{5. 胃部間接（外来スクリーニング）の一年間の経験}

茅ケ崎市立病走院

百 瀬宏・本庄 重雄

此域市民の成人病への関心の高まりと共に当院内科外 来患者のうち消化器愁訴の患者が近年增加してきた。 こ の傾问に対して胃間接検査方式を導入し，医師不足に上 る検査の遅延，被検者の制限等をなくし，䍐者サービス を尌画した。昭租144年 5 月より設犆し，今日までの1年 有余の経過をみたが，44年度における状沉㪕告をし，諸 元の御批判を仰ぎたい.

〔装四】アンダー方式ミラーカメラ $70 \mathrm{~mm}$ 発生器 120

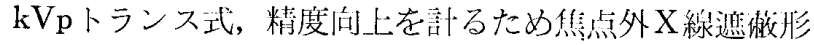
の管球と笛動多重絞りをつけた。

〔没置場所】在来の透視室を收造し，室内を隔して間 接㨐作空とし，透視台と䦌接撮影台は头行に並べた。

〔撮影条件】フォトタイマー制御による. 100〜120 $\mathrm{kVp} 150 \mathrm{~mA}$ である.

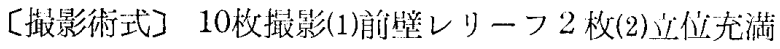
像 1 枚(3)仰卧位像 2 枚(4)シャスキの体位 1 枚(5)腹卧位像 1 枚(6)它位第 1 斜位像 1 枚(7)立位第 2 斜位像 1 枚(8)食道 像 1 枚.

〔スクリーニングの成續】44年 5 月〜 45位 3 月間接受 䛦人員 559 人（直接 621 人）間接より要精検 52 人， $9.3 \%$, 资患発見 34 人， $6 \%$ ，谓接 621 上り発見将患 143 人， $23 \%$ ，

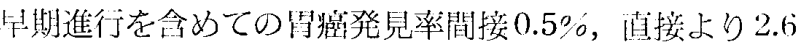
$\%$.

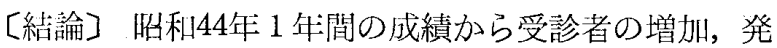
見疾患率の向上等により，克分外来スクリーニングの目 的は達成している，今年度には 4 力月で 400 人を垁施し
て間接影影の量的増加は著しく市民医燎サービスの一端 を充分尽している. 今後の問題点としては撮影術式の検 討と体位と䛈患発見との関係を研究課題としている.

16. Isodensitometry によるX 線画像強調について

国立がんセンター 松本 健

X線㝍吉に含まれる情報をより多く適確に引き出す為 に色々の方法が考えられて居るがその多くは，像を一度 アナログ量として取り出し, 種々の処理を加えて, 再び 画像に復現するか, 又は，数値として表現するか，のい ずれかの法が取られて居ると思われる。

在来の䓂断方法より見れば，前者の画像として再現さ せる方法が便利であるうと考えられる，その油像が元の 两像より容易により多くの情報を観察出来る画像でなく てはならない。

ここでは，等濃度測定 (Isodensitometry) の手法を用 い，X線像を，適当に選んだ濃度についてその分布を测 定し, その像を元の, X線像と重稀わせ, 特定の部分 を, 強調して, 観察を容易にする事を目的とする垁験を 行なったので報出する.

\section{Subtraction (頭部) の写真的条件について}

日本医科大学第一病院 放射線科

○松山 久義・山望 一雄・池团萃好 武田 弘志・田中一蚛 - 根津 伸弘

[H的]

近年血管撮影のSubtraction Technique が，当真学的， 或いは電子工学虬に利用される様になった。ここでは, 我々が通賞行なっている䫒部血管撮影の具的条俳につ いて検詩を試みたので述べる。

[序法]

Subtraction を行なうためには，単純每点入は動解脈 像写真揌奏に反転再現した密着写真が必要である.

我々は，従来の方法である増感紙を䏘いた螢光焼付法

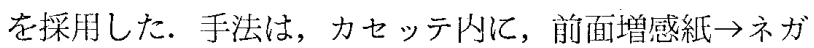
写基 $\rightarrow$ 感光材（医療用フィルム或いはグラビアフィルム 等) $\rightarrow$ 黒紬 (後面螢光の俌断胿) の順序に重ね, X線を暴 射してポジ像を作成する。作成した密着守真でSubtractionを行なう, 刘像写真に正確に重的合せ，セロテープ 固定を施して先の螢光焼付法, 或いは一般写真用引伸機

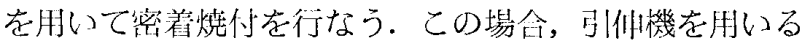
方法では，フィルム相互の目着を計るため，透明ガラス 板とハレション防止用の黒紙でサンド固定した. 使用感 光材は，医療用フィルム及びグラビアフィルムを用い， 更に Subtraction 手技を敏速に行なうため現像好理は的 
現装犆を用いている.

一方，使用感材並びに自現処理法では，写真的に硬調 化の傾向があるので撰択的に，パンドールミクロファイ ン処理剂等を用い，適正写真の作成を試みている.

[結果]

Subtraction の写真的条件について検討を行ない次の 諸点を明らか沉した。

(1)増感紙の螢光々源を用いる方法で写真的条件の規格化 を計った，又(2)本法は手技が簡単で能率的であった（3) グラビアフィルム及び医療用フィルムの単独立びに組み 合せ使用で罙真の質的向上が得られた。

\section{8. 増感紙の鮮鋭度管電圧特性}

\section{大日本叙料 $\mathrm{KK}$ 平城 実}

〔目的〕増感紙の鮮鋭度は，ある程度撮影管電圧（線 質）に依存すると言われている．乙の管電圧による䱮鋭 度の変化について増感紙の構成との関係を検討した。

〔方法]増感紙として,フロント・バックの構成の暴 なった 2 種類について，管電圧 $50 \sim 150 \mathrm{kVp}$ の範囲で実 験し, 鮮鋭度は矩形波チャート法によるMTFによりU $=1$ 本 $/ \mathrm{mm}$ で単一評価した。

〔結果〕(1) kVpによる鮮鋭度の変化は少ないが，シン グルの場合フロント・バックで異なった傾向を示す.コ ンビの場合はフロント・バックの特性の異った増感紙程 その変化は大きく，管電圧の上昇に伴い低下する，FS 增感紙では $\mathrm{kVp}$ による鮮鋭度の変化は少なかった。

(2) コンビの MTF はシングルの MTF から次の式 Mt $(\mathrm{u})=\mathrm{KMf}(\mathrm{u})+(1-\mathrm{K}) \mathrm{Mb}(\mathrm{u})$ より求めたものと実測と よい一致をみた。

(3)高電圧で MTF を測定する場合, 測定精度のためチャ 一トとして吸収の大きい材質で, 愿さが必要で, この奏 験ではW製 $0.2 \mathrm{~mm}$ を使用した。

\section{函19. 当放射線科 5 ケ年間（40～44年）の作業量の推移 ( $X$ 線関係)}

\author{
長野赤十字病院 放射線科 \\ 高橋 善助・三井 三男・馬場袈裟三.
}

過去 5 年間の一般撮影, 消化器, 特殊撮影のX線曝射 件数, 及び稼㗢点, フィルム使用量等の年次別推移を集 約したので発表する.

(1) 一般撮影年度別総件数及び総点数

(2) 消化器の年度別総件数

(3) (2)の造影総件数

(4) 特殊撮影の年度別総件数

(5)一般撮影, 消化器, 他, 特殊撮影, 入院, 外来総
件数 (年度別, 月別)

(6) 年度別, サイズ別, フィルム使用枚数各月フィル 么使用枚数

(7) 技師一人の年平均作業量及び稼働点

(8) 当放射線科平面図

(9) 年度別再撮, 研究用フィルム枚数

年度によって取扱件数及び稼働点, フィルム枚数の増 加の一因は放射線科, 内科の充実, 神経科の新設等入院 ベッド数の増加によるものと思考する.

尚放射線技師の大きな課題である定員制（業務媓の規 準）については，各職場の㬰態の中から検討するととは 賢明な一方法であり，本調査の何年度が現人員において 要当な適正作業量であるかを全国日赤同一程度の病院放 射線科をアンケートに依り集約し, 絲合的に検討を加え そのПで発表したい.

廆20.上伊那地方における結核登録患者の実態

桝那保健所

小林 千文

S 44年末現在で当管内に 1,173 名の結核登録患者があ り，その中に肺結核の感染性の者が 131 名あったとの 結核登録患者について分析したので報告する。

年路別には 5〜14 歳に小さな山，40歳以上に大きな山 があり国保の世帯主に最も多い. 職業別には無職が多い のは国の統計と同じであるが，農業従事者も多いのは当 此区が農業人口が多いせいであろうか. S40年以前に登 録されたままの患者が約半数あり治りきらない人も多く， 治塐を要するあので医療を全く施してないものあ多数あ った.

結核は低所得階層でしかも働き盛りの男性に多く社会 的問題として樑刻である.

\section{○特 別 講 演}

\section{「放射線医学における診断と治療の間」}

信州大学医学部教授 小林敏雄先生

21. ベータトロンラジオグラフィーについて 長野県立 木笮病院 吉村 喜等

[目的]

ベータトロン放射線治療の実施に際し, 線量分布を知 るため, 各エネルギーとコーンについて, ラジオグラフ イ一を行ない，その濃度差により，線量分布図を作成す る.

丈, ベータトロンX線を利用して, 胸部, 頸部, 頭部 の撮影を行なったのでその2〜3の例について報告するる. 